\title{
Second- and third-generation ALK inhibitors for non-small cell lung cancer
}

Jingjing $\mathrm{Wu}^{1}$, John Savooji ${ }^{2}$ and Delong Liu' ${ }^{*}$

\begin{abstract}
Crizotinib as the first-generation ALK inhibitor has shown significant activity in ALK-mutated non-small cell lung cancer (NSCLC). Second- and third-generation ALK inhibitors are entering clinical applications for ALK+ NSCLC. In addition, a third-generation ALK inhibitor, lorlatinib (PF-06463922), was reported to resensitize NSCLC to crizotinib. This review provided a summary of clinical development of alectinib, ceritinib, brigatinib (AP26113), and lorlatinib.
\end{abstract}

\section{Background}

Small molecule inhibitors of EGFR (epidermal growth factor receptor) have been widely used for lung cancer therapy [1-9]. A small subset (3-13\%) of non-small cell lung cancer (NSCLC) has been shown to have rearrangements in the $A L K$ (anaplastic lymphoma kinase) gene $[10,11]$. Over the last few years, ALK inhibitors have shown significant benefits in the management of ALKpositive NSCLC compared to conventional chemotherapy [12-15]. A big caveat however is the emergence of resistance to ALK inhibitors [16]. This article provided a summary of clinical development of alectinib, ceritinib, brigatinib (AP26113), and lorlatinib for NSCLC.

\section{$A L K$ gene and the roles in oncogenesis}

The $A L K$ gene encodes for ALK receptor tyrosine kinase enzyme. The gene is located on the short arm of chromosome 2 (2p23) and belongs to the insulin receptor superfamily. Like other receptor tyrosine kinases, it has an extracellular domain, a transmembrane segment, and a cytoplasmic receptor kinase segment [17]. Physiologically, ALK is involved in the development of brain and neurons [18]. It is highly expressed during embryogenesis and thereafter becomes dormant. ALK mutation can lead to tumorigenesis [19]. Most mutations of the $A L K$ gene are in the form of a translocation with another partner gene leading to a fusion oncogene which becomes overtly expressed in cancers [20] (Fig. 1). The first ALK mutation was reported in 1994 when NPM-

\footnotetext{
* Correspondence: Delong_liu@nymc.edu

${ }^{1}$ Department of Oncology, The First Affiliated Hospital of Zhengzhou

University, Zhengzhou, China

Full list of author information is available at the end of the article
}

$A L K$ was described in a subset of anaplastic large cell lymphomas [21]. This mutation involves fusion of the nucleophosmin (NPM) gene and $A L K$ as a result of $\mathrm{t}(2 ; 5)(\mathrm{p} 23 ; \mathrm{q} 35)$ [21, 22]. Additional gene partners have been discovered in fusion oncogenes with $A L K$ gene. A few examples are TPM3-t $(1 ; 2)(\mathrm{q} 25 ; \mathrm{p} 23), T F G-$ $\mathrm{t}(2 ; 3)(\mathrm{p} 23 ; \mathrm{q} 21), \quad C L T C L 1-\mathrm{t}(2 ; 17)(\mathrm{p} 23 ; \mathrm{q} 23)$, and ATICinv(p23;q35) [22]. More mutations of $A L K$ gene have been reported in several cancers, including NSCLC, inflammatory myofibroblastic tumors, diffuse large B cell lymphoma, colon cancer, renal cell carcinoma, breast carcinoma, esophageal cancer, and neuroblastoma [23].

ALK mutations were first described in NSCLC in 2007 when a subset $(7 \%)$ of Japanese patients were found to have echinoderm microtubule associated protein like-4 (EML4) rearrangement with ALK leading to a fusion oncogene EML4-ALK [24, 25]. This was due to an inversion rearrangement from $\operatorname{inv}(2)(\mathrm{p} 21 ; \mathrm{p} 23)$. As a result, EML4 replaces the extracellular and intramembranous parts of $A L K$ and fuses with the juxta membranous part. The EML4-ALK gene induced tumor formation in nude mice [23, 24]. Due to different breakpoint on EML4, several variants of $E M L 4-A L K$ mutation have been described [10, 26, 27]. EML4-ALK variants with differing frequencies are V1 (54.5\%), V2 (10 \%), V3a/V3b (34 \%), and V5a (1.5 \%) [26, 27]. Rearrangements of the $A L K$ gene with partner genes other than $E M L 4$ have been described, namely, KIF5B, KLC1, TFG, TPR, HIP1, STRN, DCTN1, SQSTM1, and BIRC6 [28] (Fig. 1).

$A L K$ translocations result in increased tyrosine kinase activity leading to increased cell proliferation and survival and ultimately tumorigenesis. The ALK signaling pathways involve phospholipase $\mathrm{C} \gamma$ (PLCY), Janus kinase 


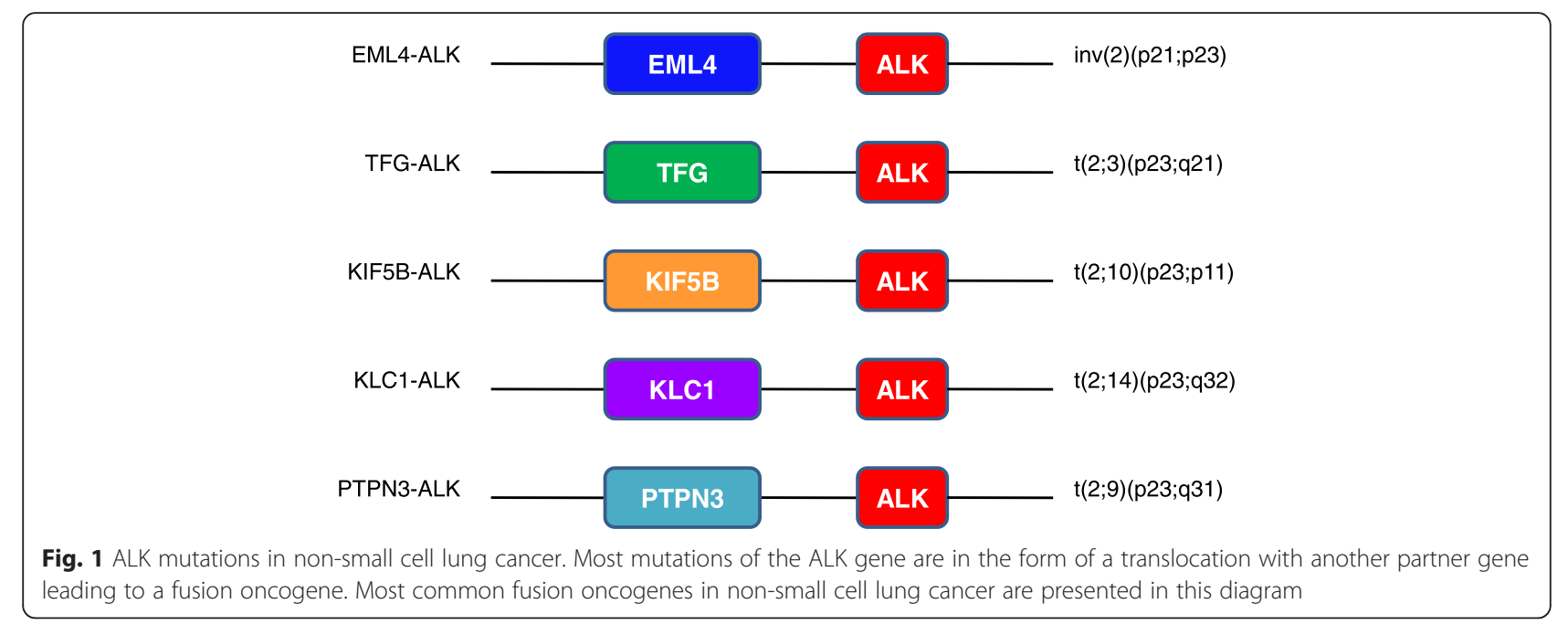

(JAK)-signal transducer and activator of transcription (STAT), PI3K-AKT, mTOR, sonic hedgehog (SHH), JUN-B, CRKL-C3G (also known as RAPGEF1), RAP1 GTPase, and MAPK signaling cascades [23].

\section{ALK $^{+}$NSCLC characteristics}

$A L K$-positive NSCLCs are generally seen in non-smokers, occur at a younger age, and are mostly adenocarcinoma in histology [15]. They also seem to have a female gender predisposition [11-13, 27]. Pathological features include solid morphology and presence of signet ring cells $[29,30]$.

\section{Crizotinib (PF-02341066, xalkori)}

Crizotinib (PF-02341066, xalkori) is the first-generation ALK inhibitor approved for $A L K$-positive NSCLC [12]. It has a $\mathrm{IC}_{50}$ against $E M L 4-A L K$ of $250-300 \mathrm{~nm}$ [31]. In addition to having activity against $A L K$, it also has activity against c-MET and ROS1 tyrosine kinases [31-34]. It was approved for $A L K$ positive, locally advanced, and metastatic NSCLC [35].

The PROFILE 1007 study involving 347 patients with $A L K$-positive NSCLC compared crizotinib with chemotherapy in patients who failed at least one prior platinum-containing regimen [13]. These patients were randomly assigned to receive either $250 \mathrm{mg}$ twice daily of oral crizotinib vs intravenous pemetrexed or docetaxel. The median PFS was 7.7 months (95 \% CI 6.0-8.8) in crizotinib group compared with 3.0 (95\% CI 2.6-4.3) months in the chemotherapy group. The ORR was $65 \%$ (95\% CI 58-72) in crizotinib compared to $20 \%$ (95\% CI 14-26) in the chemotherapy group $(P<0.001)$ [13]. The adverse events reported were mostly grades 1 or 2 . Grade 3 or 4 events were elevated aminotransferase levels and neutropenia which occurred in 16 and $13 \%$ of patients, respectively $[13,15]$.

PROFILE 1014 study compared crizotinib vs chemotherapy in 343 patients who had no previous treatment for advanced NSCLC. They were randomized to either receive crizotinib vs pemetrexed plus platinum (cisplatin or carboplatin). Progression-free survival for crizotinib group $(n=172)$ was 10.9 months and for chemotherapy group $(n=171)$ was 7.0 months. The ORR was $74 \%(95 \%$ CI 67-81) for crizotinib group vs $45 \%$ (95 \% CI 37-53) for chemotherapy $(P<0.001)$. Median OS was not reached in either group at the time of report (hazard ratio for death with crizotinib, 0.82 ; $95 \% \mathrm{CI}, 0.54$ to $1.26 ; P=0.36$ ); the 1 -year estimated survival was $84 \%$ with crizotinib vs $79 \%$ with chemotherapy. Crizotinib-associated AEs were vision disorders, diarrhea, nausea, and edema. It was concluded from PROFILE 1014 study that crizotinib was superior to standard first-line pemetrexed-plus-platinum chemotherapy in patients with previously untreated advanced $A L K$ positive NSCLC. Hence, crizotinib is currently approved for first line in ALK+ NSCLC $[14,36]$.

Crizotinib has also been shown to be highly efficacious in ROS1-positive NSCLC which comprises $1 \%$ of all NSCLC. In a phase 1 study of 50 patients, the ORR was $72 \%$ (95 \% CI 58-84) (33 PR and 3 CR). The median PFS was 19.2 months [31]. Among 30 tumors that were tested, 7 ROS1 fusion partners were identified, 2 of these partner genes were novel. However, there was no correlation between the type of ROS1 rearrangement and the clinical response to crizotinib. ROS1 rearrangement molecularly marks a small subgroup of NSCLC for which crizotinib can play an active role in clinical therapy.

\section{Limitations of crizotinib}

Resistance to crizotinib

Majority of patients develop resistance to crizotinib within 1 to 2 years from the initiation of therapy [37]. The resistance to ALK inhibitors can be classified into primary and secondary resistance [38].

Primary resistance is seen when the tumor is deemed refractory to the agent at the beginning of the therapy 
itself as reported in chronic myeloid leukemia [39]. In the case of $A L K+$ NSCLC, the primary resistance can be attributed to the different fusion variants of EML4 with $A L K$ or other partner genes [38]. Different sensitivities to crizotinib have been shown to be dependent upon the $A L K$ variant or fusion gene partner [40, 41]. Currently, FISH has been the gold standard for detecting ALK mutations in NSCLC.

Secondary resistances are acquired mechanisms after the tumor has been exposed to an ALK inhibitor and can be further classified into two categories: ALK dominant and ALK non-dominant. In the ALK dominant type, there is mutation in the target $A L K$ gene resulting in inability to inhibit the encoded tyrosine kinase. These are termed as ALK dominant as they depend upon ALK tyrosine kinase activity [42]. Most of the mutations are in the form of point mutations and the first ones to be described are C1156Y and L1196M [43]. There have been several other secondary point mutations that have been identified and are the following: G1269A, F1174L, 1151Tins, L1152R, S1206Y, I1171T, G1202, D1203N, and V1180L [41-44].

The $A L K$ non-dominant resistance involves emergence of bypass tracks such as EGFR mutation, KRAS mutation, amplification of $K I T$, phosphorylated amplification of $E r b B, M E T$, and activation of $I G F-1 R$ in the downstream signaling. It has been shown that in the same $A L K$ resistant tumor, multiple mechanisms of resistances may occur [42, 45].

Secondary mutations of the $A L K$ gene result in $29 \%$ of resistant cases, and gene amplification is implicated in $9 \%$ of these cases. The remaining of the cases can be attributed to bypass pathways and other mechanisms that have yet to be defined [46].

\section{CNS metastasis}

Crizotinib has poor activity against CNS metastasis in NSCLC as evidenced by low concentrations detected in CNS samples during the course of systemic chemotherapy. The ratio of CNS to serum concentration of crizotinib has been in the range of $0.0006-0.001$ as established by individual case reports [47-49]. In a retrospective analysis of trials involving crizotinib, $20 \%$ of patients who did not have CNS disease at the beginning had CNS metastasis while on therapy [50]. PF-06463922 (lorlatinib) is a newly developed ALK inhibitor that has been designed for better CNS penetration and is currently in phase I/II trials (NCT01970865) (see below) [15].

In another analysis of 90 patients with brain metastases from $A L K$-mutated NSCLC, 84 of 90 patients received radiotherapy to the brain, and 86 of 90 received TKI therapy [51]. Significant improvement in this population of poor-prognostic patients was reported. The median OS after development of brain metastases was
49.5 months (95\% CI, 29.0 months to not reached), and median intracranial PFS was 11.9 months (95 \% CI, 10.1 to 18.2 months). Four groups of patients were classified in this analysis with distinct outcomes: absence of extracranial metastases, high Karnofsky performance score $\geq 90$, and no prior therapy with TKIs before development of brain metastases had longer survival $(P=.003,<.001$, and $<.001$, respectively), whereas isolated brain metastasis or initial treatment with radiation were not $(P=.633$ and .666 , respectively). It was concluded that brain radiotherapy and TKIs to control intracranial disease in $A L K+$ NSCLC can lead to prolonged survival. Newer TKIs are playing an important role in this population of patients.

\section{Crizotinib toxicity}

There have been case reports of significant adverse effects that were not reported in the initial trials. These included erythema multiforme [52], acute interstitial lung disease [53, 54], renal polycytosis [55-57], contact esophagitis [58, 59], decrease in GFR, and hypersensitivity reactions [14].

\section{Second-generation ALK inhibitors Ceritinib}

Within the first year or two after crizotinib treatment is initiated, resistance typically arises. As mentioned above, mechanisms commonly include secondary mutations within the ALK tyrosine kinase domain and activation of alternative signaling pathways. More potent and structurally different inhibitors are therefore developed.

Ceritinib (LDK378, zykadia) is a potent ALK inhibitor compared to crizotinib [60-62]. A phase I study with 130 patients with $A L K$-positive advanced tumors included 122 NSCLC [63]. The doses were 50 to $750 \mathrm{mg}$ in the dose escalation phase which enrolled 59 patients. The MTD of ceritinib was shown to be $750 \mathrm{mg}$ daily. The dose-limiting toxicities (DLT) were diarrhea, vomiting, dehydration, elevated aminotransferase levels, and hypophosphatemia. Seventy-one patients received ceritinib in the dose expansion phase. One hundred fourteen patients received ceritinib dose of at least $400 \mathrm{mg}$ daily. The ORR was $58 \%$ (95\% CI 48-67). Among the 80 patients who failed crizotinib, the response rate was $56 \%$ (95\% CI, 45 to 67). Among patients with NSCLC who received ceritinib with doses $400 \mathrm{mg}$ or higher, the median PFS was 7.0 months (95\% CI, 5.6 to 9.5).

Thus, this study proved that ceritinib induced high responses in patients who failed crizotinib. Ceritinib was approved for treatment of relapsed or refractory NSCLC after crizotinib [64] (Table 1).

\section{Alectinib}

Alectinib (CH5424802, alecensa) is a potent and highly selective inhibitor of ALK tyrosine kinase with $\mathrm{IC}_{50}$ of 
Table 1 FDA approved ALK inhibitors for non-small cell lung cancer

\begin{tabular}{|c|c|c|c|c|c|c|c|}
\hline Trials & Patients & Agents & No. & ORR & PFS & $P$ value & Refs. \\
\hline $\begin{array}{l}\text { Phase III } \\
\text { PROFILE1007 }\end{array}$ & $\begin{array}{l}\text { Relapsed } \\
\text { refractory }\end{array}$ & Crizotinib vs pemetrexed/docetaxel & $\begin{array}{l}173 \\
174\end{array}$ & $\begin{array}{l}65 \% \\
20 \%\end{array}$ & $\begin{array}{l}7.7 \mathrm{~ms} \\
3.0 \mathrm{~ms}\end{array}$ & $<0.001$ & {$[13]$} \\
\hline $\begin{array}{l}\text { Phase III } \\
\text { PROFILE1014 }\end{array}$ & Untreated & Crizotinib vs chemotherapy & $\begin{array}{l}172 \\
171\end{array}$ & $\begin{array}{l}74 \% \\
45 \%\end{array}$ & $\begin{array}{l}10.9 \mathrm{~ms} \\
7.0 \mathrm{~ms}\end{array}$ & $<0.001$ & {$[36]$} \\
\hline Phase I & Failed chemotherapy and crizotinib & Ceritinib (NSCLC, $\geq 400 \mathrm{mg}$ ) & 114 & $58 \%$ & $7.0 \mathrm{~ms}$ & N/A & [63] \\
\hline Phase I/II & Failed chemotherapy and crizotinib & Alectinib (phase II) & 46 & $94 \%$ & NA & N/A & [67] \\
\hline Phase $\mid / / I$ & Failed chemotherapy and crizotinib & Alectinib (phase II) & 47 & $55 \%$ & NA & N/A & [68] \\
\hline
\end{tabular}

Abbreviations: N/A not applicable, No. number, ORR overall response rate, DOR duration of response, PFS progression-free survival, Ref reference, wks weeks, ms months

$1.9 \mathrm{nM}[65,66]$. More importantly, it has activity against L1196M which is one of the commonly seen secondary mutations in ALK gene leading to resistance to crizotinib.

In a multicenter, single-arm, open-label phase 1-2 study conducted in Japan (AF-001JP), ALK inhibitor naïve patients who had ALK-positive NSCLC were treated with alectinib [67]. In the dose escalation phase which included 24 such patients, increasing doses in the 20-300 mg range were used. No dose-limiting toxicities (DLT) were noted. Hence, $300 \mathrm{mg}$ twice daily was established as the recommended dose for phase II. The phase II portion enrolled 46 patients. Forty-one of these patients had PR and 2 had CR. Hence, ORR was around $94 \%$ (95 \% CI: 82-98). Grade 3 adverse events were reported in $26 \%(n=12)$ and included elevated creatinine phosphokinase and neutropenia [67].

In another phase 1-2 single-arm open-label study, 47 patients with ALK-positive NSCLC who had resistance to crizotinib or were intolerant were treated with alectinib [68]. In the dose escalation phase, doses were escalated from 300 to $900 \mathrm{mg}$ in seven different cohorts of patients. DLTs were seen in the 900-mg cohort: grade 3 headache in one patient and grade 3 neutropenia in another one. Three patients dropped out of the study due to adverse events: grade 3 dyspnea, grade 4 CNS metastasis, and grade 3 abdominal pain. Out of the 47 patients, 44 were assessed for response and the ORR was found to be $55 \%$ (24 PR, one CR). ORR for the 21 patients who had baseline CNS metastasis was $52 \%$ (5 CR and another 6 having partial CNS response). Therefore, this study showed that alectinib not only was effective in patients pretreated with first-generation ALK inhibitor but also was active for CNS metastasis [68]. Alectinib is now FDA-approved for the treatment of metastatic $A L K$ + NSCLC in patients who have progressed on or are intolerant to crizotinib.

\section{Brigatinib (AP26113)}

Brigatinib is another second-generation ALK inhibitor. It is a potent dual inhibitor of ALK and EGFR, including ALK L1196M and EGFR T790M mutants, shown in preclinical and first-in-human studies [69-71]. In the initial dose-finding study, there were 18 evaluable $A L K+$ pts. Among these patients, 10 responded. Fifteen $A L K+$ pts had $0(n=3)$ or $1(n=12)$ prior ALK TKI (crizotinib); of these, $8 / 12$ pts (67\%) responded, including two complete responses. Radiographic improvement was seen in 4 of 5 $A L K+$ pts with untreated or progressing CNS lesions. There were 16 pts enrolled with EGFRm history (15 NSCLC, 1 SCLC); 14 pts had $\geq 1$ prior EGFR TKI. Of 12 EGFRm pts with a follow-up scan, 1 pt (prior erlotinib) responded at $120 \mathrm{mg}, 6 \mathrm{pts}$ had stable disease.

In the last update of the phase I/II single-arm, openlabel, multicenter study in patient pts with advanced malignancies (NCT01449461), patients received brigatinib as the following: phase I: $30-300 \mathrm{mg} /$ day total daily dose; phase II: $90 \mathrm{mg} /$ day, $180 \mathrm{mg} /$ day, or $90 \mathrm{mg} /$ day for 7 days followed by $180 \mathrm{mg} /$ day. Safety was reported in all 137 treated pts; efficacy was evaluated in all $79 A L K+$ NSCLC pts [72] (Table 2). Most common treatment-emergent adverse events (TEAE) included nausea, diarrhea, fatigue, cough, and headache. Early-onset

Table 2 Brigatinib and lorlatinib in clinical development for non-small cell lung cancer

\begin{tabular}{llllll}
\hline Trials & Agents & Patients & No. & ORR & PFS \\
\hline Phase I/II & Brigatinib & Crizotinib-naive & 76538 & $7 / 7(100 \%)$ & 56 weeks \\
(NCT01449461) & & Crizotinib-failure & & $45 / 65(69 \%)$ & 47 weeks \\
& & with CNS metastases & & $14 / 38(37 \%)$ & 97 weeks \\
Phase I/II & Lorlatinib & Untreated & N/A & N/A & N/A \\
(NCT01970865) & & Failed 1 ALKi & & & [77]
\end{tabular}

Abbreviations: N/A not applicable, ORR overall response rate, DOR duration of response, PFS progression-free survival, Ref reference, wks weeks, $m$ months, ALKi ALK inhibitor 
pulmonary events were observed less frequently with the 90-mg starting dose compared with higher doses. Median progression-free survival (PFS) is 56 weeks, 47 weeks with prior crizotinib. In pts with baseline CNS metastases, half of 12 pts had a brain response and 8/26 pts with only non-measurable lesions had disappearance of all lesions. Median intracranial PFS for these pts is 97 weeks. Therefore, brigatinib was active in crizotinib-resistant NSCLC and showed activity in CNS lesions. A randomized phase 2 trial of brigatinib in crizotinib-resistant $A L K+$ NSCLC (ALTA) is underway.

\section{Third-generation ALK inhibitor}

Lorlatinib (PF-06463922) is a novel, reversible, potent ATP-competitive small molecule inhibitor of ALK and ROS1. This third-generation inhibitor is effective against all known resistant mutants [73-75]. In preclinical studies, lorlatinib was proven to be active in crizotinib-resistant cancers both in vitro and in xenograft models [73-75]. To overcome $A L K$ mutations and ALK inhibitor resistance, lorlatinib was combined with PI3K pathway inhibitors, such as PF-05212384 (PI3K/mTOR), GDC0941 (pan-PI3K), or GDC0032 (beta-sparing). Such rational combination was reported to lead to more robust activity in vitro and greater duration of efficacy in vivo in the ALK inhibitor resistant models [76].

Lorlatinib is being studied in a phase I clinical trial in patients who were refractory to crizotinib and ceritinib (NCT01970865) [77]. One patient enrolled to this trial responded to lorlatinib for 8 months. Interestingly, the patient was resensitized to crizotinib after the patient failed the lorlatinib treatment, indicating that retreatment under molecular guidance can be a clinically meaningful approach.

\section{Conclusions}

Second- and third-generation ALK inhibitors are entering clinical applications for ALK+ NSCLC. Among these, dual inhibitors targeting ALK as well as EGFRm and ROS1 may provide additional benefits for crizotinibrefractory patients. Resensitization to and retreatment with crizotinib can be considered under molecular guidance. More and more biomarker-targeted agents are entering clinical applications [78-81]. Immune therapies are showing remarkable benefits [82-91]. It is foreseeable that combination of these novel agents and small molecular inhibitors may expand the potential for treatment of refractory lung cancer patients.

\section{Competing interests}

The authors declare that they have no competing interests.

\section{Authors' contributions}

DL designed the study. JW, JS, and DL drafted the manuscript. DL and JW designed and finalized the figure preparation and tables. All authors read and approved final manuscript.

\section{Acknowledgement}

Jingjing Wu is a recipient of the Henan Provincial Grant for Overseas Research for Young Leaders of Medical Technology (No. 2014041). In addition, Jingjing Wu also received grant support from the Natural Science Foundation of China (NSFC No. 81201793). The grants supported her research training at the Division of Hematology and Oncology, New York Medical College, USA.

\section{Author details}

${ }^{1}$ Department of Oncology, The First Affiliated Hospital of Zhengzhou University, Zhengzhou, China. ${ }^{2}$ Department of Medicine, Westchester Medical Center and New York Medical College, Valhalla, NY 10595, USA.

Received: 27 January 2016 Accepted: 1 March 2016

Published online: 08 March 2016

References

1. Lee CK, Wu Y-L, Ding PN, Lord SJ, Inoue A, Zhou C, et al. Impact of specific epidermal growth factor receptor (EGFR) mutations and clinical characteristics on outcomes after treatment with EGFR tyrosine kinase inhibitors versus chemotherapy in EGFR-mutant lung cancer: a metaanalysis. J Clin Oncol. 2015;33(17):1958-65.

2. Cataldo VD, Gibbons DL, Perez-Soler R, Quintas-Cardama A. Treatment of non-small-cell lung cancer with erlotinib or gefitinib. N Engl J Med. 2011; 364(10):947-55.

3. Maheswaran S, Sequist L, Nagrath S, Ulkus L, Brannigan B, Collura C. Detection of mutations in EGFR in circulating lung-cancer cells. N Engl J Med. 2008;359(4):366-77.

4. Murtaza M, Dawson S, Tsui D, Gale D, Forshew T, Piskorz A. Non-invasive analysis of acquired resistance to cancer therapy by sequencing of plasma DNA. Nature. 2013;497(7447):108-12.

5. Sun W, Yuan X, Tian Y, Wu H, Xu H, Hu G, et al. Non-invasive approaches to monitor EGFR-TKI treatment in non-small-cell lung cancer. J Hematol Oncol. 2015;8(1):95.

6. Wang S, Su X, Bai H, Zhao J, Duan J, An T, et al. Identification of plasma microRNA profiles for primary resistance to EGFR-TKls in advanced nonsmall cell lung cancer (NSCLC) patients with EGFR activating mutation. J Hematol Oncol. 2015;8(1):127.

7. Zhong W, Yang X, Yan H, Zhang X, Su J, Chen Z, et al. Phase II study of biomarker-guided neoadjuvant treatment strategy for IIIA-N2 non-small cell lung cancer based on epidermal growth factor receptor mutation status. J Hematol Oncol. 2015;8(1):54.

8. Niu F, Wu Y. Novel agents and strategies for overcoming EGFR TKls resistance. Exp Hematol Oncol. 2014;3(1):2.

9. Tsao M, Sakurada A, Cutz J, Zhu C, Kamel-Reid S, Squire J. Erlotinib in lung cancer-molecular and clinical predictors of outcome. New Engl J Med. 2005;353(2):133-44.

10. Horn L, Pao W. EML4-ALK: honing in on a new target in non-small-cell lung cancer. J Clin Oncol. 2009;27(26):4232-5.

11. Shaw AT, Yeap BY, Mino-Kenudson M, Digumarthy SR, Costa DB, Heist RS, et al. Clinical features and outcome of patients with non-small-cell lung cancer who harbor EML4-ALK. J Clin Oncol. 2009;27(26):4247-53.

12. Kwak EL, Bang YJ, Camidge DR, Shaw AT, Solomon B, Maki RG, et al Anaplastic lymphoma kinase inhibition in non-small-cell lung cancer. N Engl J Med. 2010;363(18):1693-703.

13. Shaw AT, Kim DW, Nakagawa K, Seto T, Crino L, Ahn MJ, et al. Crizotinib versus chemotherapy in advanced ALK-positive lung cancer. N Engl J Med. 2013;368(25):2385-94.

14. Solomon B. Refining the toxicity profile of crizotinib. J Thorac Oncol. 2014; 9(11):1596-7.

15. Iragavarapu C, Mustafa M, Akinleye A, Furqan M, Mittal V, Cang S, et al. Novel ALK inhibitors in clinical use and development. J Hematol Oncol. 2015;8(1):17.

16. Isozaki H, Takigawa N, Kiura K. Mechanisms of acquired resistance to ALK inhibitors and the rationale for treating ALK-positive lung cancer. Cancers (Basel). 2015;7(2):763-83.

17. Duyster J, Bai RY, Morris SW. Translocations involving anaplastic lymphoma kinase (ALK). Oncogene. 2001;20(40):5623-37.

18. Webb TR, Slavish J, George RE, Look AT, Xue L, Jiang Q, et al. Anaplastic lymphoma kinase: role in cancer pathogenesis and small-molecule inhibitor development for therapy. Expert Rev Anticancer Ther. 2009;9(3):331-56. 
19. Iwahara T, Fujimoto J, Wen D, Cupples R, Bucay N, Arakawa T, et al. Molecular characterization of ALK, a receptor tyrosine kinase expressed specifically in the nervous system. Oncogene. 1997;14(4):439-49.

20. Kelleher FC, McDermott R. The emerging pathogenic and therapeutic importance of the anaplastic lymphoma kinase gene. Eur J Cancer. 2010;46(13):2357-68.

21. Morris SW, Kirstein MN, Valentine MB, Dittmer KG, Shapiro DN, Saltman DL, et al. Fusion of a kinase gene, ALK, to a nucleolar protein gene, NPM, in non-Hodgkin's lymphoma. Science. 1994;263(5151):1281-4.

22. Boi M, Zucca E, Inghirami G, Bertoni F. Advances in understanding the pathogenesis of systemic anaplastic large cell lymphomas. Br J Haematol. 2015;168(6):771-83.

23. Hallberg $B$, Palmer $\mathrm{RH}$. Mechanistic insight into ALK receptor tyrosine kinase in human cancer biology. Nat Rev Cancer. 2013;13(10):685-700.

24. Soda M, Choi YL, Enomoto M, Takada S, Yamashita Y, Ishikawa S, et al. Identification of the transforming EML4-ALK fusion gene in non-small-cell lung cancer. Nature. 2007;448(7153):561-6.

25. Takeuchi K, Choi YL, Soda M, Inamura K, Togashi Y, Hatano S, et al. Multiplex reverse transcription-PCR screening for EML4-ALK fusion transcripts. Clin Cancer Res. 2008;14(20):6618-24.

26. Choi YL, Takeuchi K, Soda M, Inamura K, Togashi Y, Hatano S, et al. Identification of novel isoforms of the EML4-ALK transforming gene in non-small cell lung cancer. Cancer Res. 2008;68(13):4971-6.

27. Li T, Maus MK, Desai SJ, Beckett LA, Stephens C, Huang E, et al. Large-scale screening and molecular characterization of EML4-ALK fusion variants in archival non-small-cell lung cancer tumor specimens using quantitative reverse transcription polymerase chain reaction assays. J Thorac Oncol. 2014;9(1):18-25.

28. Iyevleva AG, Raskin GA, Tiurin VI, Sokolenko AP, Mitiushkina NV, Aleksakhina SN, et al. Novel ALK fusion partners in lung cancer. Cancer Lett. 2015;362(1):116-21.

29. Nishino M, Klepeis VE, Yeap BY, Bergethon K, Morales-Oyarvide V, DiasSantagata D, et al. Histologic and cytomorphologic features of ALKrearranged lung adenocarcinomas. Mod Pathol. 2012;25(11):1462-72.

30. Yoshida A, Tsuta K, Nakamura H, Kohno T, Takahashi F, Asamura H, et al. Comprehensive histologic analysis of ALK-rearranged lung carcinomas. Am J Surg Pathol. 2011;35(8):1226-34.

31. Shaw AT, Ou SH, Bang YJ, Camidge DR, Solomon BJ, Salgia R, et al. Crizotinib in ROS1-rearranged non-small-cell lung cancer. N Engl J Med. 2014;371(21):1963-71.

32. Cui JJ, Tran-Dube M, Shen H, Nambu M, Kung PP, Pairish M, et al. Structure based drug design of crizotinib (PF-02341066), a potent and selective dual inhibitor of mesenchymal-epithelial transition factor (c-MET) kinase and anaplastic lymphoma kinase (ALK). J Med Chem. 2011;54(18):6342-63.

33. Yasuda H, de Figueiredo-Pontes LL, Kobayashi S, Costa DB. Preclinical rationale for use of the clinically available multitargeted tyrosine kinase inhibitor crizotinib in ROS1-translocated lung cancer. J Thorac Oncol. 2012;7(7):1086-90.

34. Zou HY, Li Q, Lee JH, Arango ME, McDonnell SR, Yamazaki S, et al, An orally available small-molecule inhibitor of c-Met, PF-2341066, exhibits cytoreductive antitumor efficacy through antiproliferative and antiangiogenic mechanisms. Cancer Res. 2007;67(9):4408-17.

35. Camidge DR, Bang YJ, Kwak EL, lafrate AJ, Varella-Garcia M, Fox SB, et al. Activity and safety of crizotinib in patients with ALK-positive non-small-cell lung cancer: updated results from a phase 1 study. Lancet Oncol. 2012;13(10):1011-9.

36. Solomon BJ, Mok T, Kim D-W, Wu Y-L, Nakagawa K, Mekhail T, et al. First-line crizotinib versus chemotherapy in ALK-positive lung cancer. N Engl J Med. 2014;371(23):2167-77.

37. Shaw AT, Engelman JA. Ceritinib in ALK-rearranged non-small-cell lung cancer. N Engl J Med. 2014;370(26):2537-9.

38. Duchemann B, Friboulet L, Besse B. Therapeutic management of ALK+ nonsmall cell lung cancer patients. Eur Respir J. 2015:46(1):230-42.

39. Quintas-Cardama A, Kantarjian HM, Cortes JE. Mechanisms of primary and secondary resistance to imatinib in chronic myeloid leukemia. Cancer Control. 2009;16(2):122-31.

40. Heuckmann JM, Balke-Want H, Malchers F, Peifer M, Sos ML, Koker M, et al. Differential protein stability and ALK inhibitor sensitivity of EML4-ALK fusion variants. Clin Cancer Res. 2012;18(17):4682-90.

41. Heuckmann JM, Holzel M, Sos ML, Heynck S, Balke-Want H, Koker M, et al. ALK mutations conferring differential resistance to structurally diverse ALK inhibitors. Clin Cancer Res. 2011;17(23):7394-401.
42. Toyokawa G, Seto T. Updated evidence on the mechanisms of resistance to ALK inhibitors and strategies to overcome such resistance: clinical and preclinical data. Oncol Res Treat. 2015;38(6):291-8.

43. Choi YL, Soda M, Yamashita Y, Ueno T, Takashima J, Nakajima T, et al. EML4-ALK mutations in lung cancer that confer resistance to ALK inhibitors. N Engl J Med. 2010;363(18):1734-9.

44. Sasaki T, Okuda K, Zheng W, Butrynski J, Capelletti M, Wang L, et al. The neuroblastoma-associated F1174L ALK mutation causes resistance to an ALK kinase inhibitor in ALK-translocated cancers. Cancer Res. 2010;70(24):10038-43.

45. Katayama R, Shaw AT, Khan TM, Mino-Kenudson M, Solomon BJ, Halmos B, et al. Mechanisms of acquired crizotinib resistance in ALK-rearranged lung cancers. Sci Transl Med. 2012;4(120):120ra117.

46. Awad MM, Shaw AT. ALK inhibitors in non-small cell lung cancer: crizotinib and beyond. Clin Adv Hematol Oncol. 2014;12(7):429-39.

47. Costa DB, Kobayashi S, Pandya SS, Yeo WL, Shen Z, Tan W, et al. CSF concentration of the anaplastic lymphoma kinase inhibitor crizotinib. J Clin Oncol. 2011:29(15):e443-5.

48. Klempner SJ, Ou SH. Anaplastic lymphoma kinase inhibitors in brain metastases from ALK+ non-small cell lung cancer: hitting the target even in the CNS. Chin Clin Oncol. 2015;4(2):20.

49. Metro G, Lunardi G, Floridi P, Pascali JP, Marcomigni L, Chiari R, et al. CSF concentration of crizotinib in two ALK-positive non-small-cell lung cancer patients with CNS metastases deriving clinical benefit from treatment. J Thorac Oncol. 2015;10(5):e26-7.

50. Costa DB, Shaw AT, Ou SH, Solomon BJ, Riely GJ, Ahn MJ, et al. Clinical experience with crizotinib in patients with advanced ALK-rearranged nonsmall-cell lung cancer and brain metastases. J Clin Oncol. 2015;33(17):1881-8.

51. Johung KL, Yeh N, Desai NB, Williams TM, Lautenschlaeger T, Arvold ND, et al. Extended survival and prognostic factors for patients with ALKrearranged non-small-cell lung cancer and brain metastasis. J Clin Oncol. 2016;34(2):123-9.

52. Sawamura S, Kajihara I, Ichihara A, Fukushima S, Jinnin M, Yamaguchi E, et al. Crizotinib-associated erythema multiforme in a lung cancer patient. Drug Discov Ther. 2015:9(2):142-3.

53. Deiana L, Grisanti S, Ferrari V, Tironi A, Brugnoli G, Ferrari L, et al. Aspergillosis superinfection as a cause of death of crizotinib-induced interstitial lung disease successfully treated with high-dose corticosteroid therapy. Case Rep Oncol. 2015:8(1):169-73.

54. Maka W, Krishnaswamy UM, Anil Kumar N, Chitrapur R, Kilara N. Acute interstitial lung disease in a patient with anaplastic lymphoma kinasepositive non-small-cell lung cancer after crizotinib therapy. Oxf Med Case Reports. 2014;2014(1):11-2

55. Di Girolamo M, Paris I, Carbonetti F, Onesti EC, Socciarelli F, Marchetti $P$. Widespread renal polycystosis induced by crizotinib. Tumori. 2015;101(4):e128-31.

56. Schnell P, Bartlett CH, Solomon BJ, Tassell V, Shaw AT, de Pas T, et al. Complex renal cysts associated with crizotinib treatment. Cancer Med. 2015;4(6):887-96.

57. Souteyrand P, Burtey S, Barlesi F. Multicystic kidney disease: a complication of crizotinib. Diagn Interv Imaging. 2015;96(4):393-5.

58. Conduit C, Wilson M, Hunter K, Murdolo V, Nott L. Severe contact esophagitis in a patient taking crizotinib: a case report. Asia Pac J Clin Oncol. 2015:11(2):187-9.

59. Yoneshima Y, Okamoto I, Takano T, Enokizu A, Iwama E, Harada T, et al. Successful treatment with alectinib after crizotinib-induced esophageal ulceration. Lung Cancer. 2015;88(3):349-51.

60. Friboulet L, Li N, Katayama R, Lee CC, Gainor JF, Crystal AS, et al. The ALK inhibitor ceritinib overcomes crizotinib resistance in non-small cell lung cancer. Cancer Discov. 2014;4(6):662-73.

61. Marsilje TH, Pei W, Chen B, Lu W, Uno T, Jin Y, et al. Synthesis, structureactivity relationships, and in vivo efficacy of the novel potent and selective anaplastic lymphoma kinase (ALK) inhibitor 5-chloro-N2-(2-isopropoxy-5methyl-4-(piperidin-4-yl)phenyl)-N4-(2-(isopropylsulf onyl)phenyl)pyrimidine2,4-diamine (LDK378) currently in phase 1 and phase 2 clinical trials. J Med Chem. 2013;56(14):5675-90.

62. Rolfo C, Passiglia F, Russo A, Pauwels P. Looking for a new panacea in ALKrearranged NSCLC: may be ceritinib? Expert Opin Ther Targets. 2014;18(9):983-5.

63. Shaw AT, Kim D-W, Mehra R, Tan DSW, Felip E, Chow LQM, et al. Ceritinib in ALK-rearranged non-small-cell lung cancer. N Engl J Med. 2014;370(13):1189-97.

64. Chabner BA. Approval after phase I: ceritinib runs the three-minute mile. Oncologist. 2014;19(6):577-8. 
65. Kinoshita K, Asoh K, Furuichi N, Ito T, Kawada H, Hara S, et al. Design and synthesis of a highly selective, orally active and potent anaplastic lymphoma kinase inhibitor (CH5424802). Bioorg Med Chem. 2012;20(3):1271-80.

66. Sakamoto H, Tsukaguchi T, Hiroshima S, Kodama T, Kobayashi T, Fukami TA, et al. CH5424802, a selective ALK inhibitor capable of blocking the resistant gatekeeper mutant. Cancer Cell. 2011;19(5):679-90.

67. Seto T, Kiura K, Nishio M, Nakagawa K, Maemondo M, Inoue A, et al. CH5424802 (RO5424802) for patients with ALK-rearranged advanced nonsmall-cell lung cancer (AF-001.JP study): a single-arm, open-label, phase 1-2 study. Lancet Oncol. 2013;14(7):590-8.

68. Gadgeel SM, Gandhi L, Riely GJ, Chiappori AA, West HL, Azada MC, et al. Safety and activity of alectinib against systemic disease and brain metastases in patients with crizotinib-resistant ALK-rearranged non-smallcell lung cancer (AF-002JG): results from the dose-finding portion of a phase 1/2 study. Lancet Oncol. 2014;15(10):1119-28.

69. Camidge DR, Bazhenova L, Salgia R, Weiss GJ, Langer CJ, Shaw AT, et al. First-in-human dose-finding study of the ALK/EGFR inhibitor AP26113 in patients with advanced malignancies: updated results. ASCO Meeting Abstracts. 2013;31(15_suppl):8031.

70. Huang W-S, Li F, Cai L, Xu Y, Zhang S, Wardwell SD, et al. Abstract 2827: discovery of AP26113, a potent, orally active inhibitor of anaplastic lymphoma kinase and clinically relevant mutants. Cancer Res. 2015;75(15 Supplement):2827.

71. Zhang S, Nadworny S, Wardwell SD, Eichinger L, Das B, Ye EY, et al. Abstract 781: the potent ALK inhibitor AP26113 can overcome mechanisms of resistance to first- and second-generation ALK TKIs in preclinical models. Cancer Res. 2015;75(15 Supplement):781.

72. Camidge DR, Bazhenova L, Salgia R, Langer CJ, Gold KA, Rosell R, et al. Safety and efficacy of brigatinib (AP26113) in advanced malignancies, including ALK+ non-small cell lung cancer (NSCLC). ASCO Meeting Abstracts. 2015;33(15_suppl):8062.

73. Zou HY, Friboulet L, Kodack DP, Engstrom LD, Li Q, West M, et al. PF06463922, an ALK/ROS1 inhibitor, overcomes resistance to first and second generation ALK inhibitors in preclinical models. Cancer Cell. 2015:28(1):70-81.

74. Tucker ER, Danielson LS, Innocenti P, Chesler L. Tackling crizotinib resistance: the pathway from drug discovery to the pediatric clinic. Cancer Res. 2015: 75(14):2770-4

75. Infarinato NR, Park JH, Krytska K, Ryles HT, Sano R, Szigety KM, et al. The ALK/ROS1 inhibitor PF-06463922 overcomes primary resistance to crizotinib in ALK-driven neuroblastoma. Cancer Discovery. 2016;6(1):96-107.

76. Wei P, Qiu M, Lee N, Cao J, Wang H, Tsaparikos K, et al. Abstract 764: rational combination of PF-06463922 (next-generation ALK inhibitor) with PI3K pathway inhibitors overcomes ALKi resistance in EML4-ALK+ NSCLC models. Cancer Res. 2015;75(15 Supplement):764.

77. Shaw AT, Friboulet L, Leshchiner I, Gainor JF, Bergqvist S, Brooun A, et al. Resensitization to crizotinib by the lorlatinib ALK resistance mutation L1198F. N Engl J Med. 2016;374(1):54-61.

78. Gravina G, Senapedis W, McCauley D, Baloglu E, Shacham S, Festuccia C. Nucleo-cytoplasmic transport as a therapeutic target of cancer. J Hematol Oncol. 2014;7(1):85.

79. Smith A, Roda D, Yap T. Strategies for modern biomarker and drug development in oncology. J Hematol Oncol. 2014;7(1):70.

80. Yuan $\mathrm{X}, \mathrm{Wu} \mathrm{H}, \mathrm{Han} \mathrm{N}, \mathrm{Xu} \mathrm{H}, \mathrm{Chu} \mathrm{Q}, \mathrm{Yu}$ S, et al. Notch signaling and EMT in non-small cell lung cancer: biological significance and therapeutic application. J Hematol Oncol. 2014;7(1):87.

81. Tibes $R$, Mesa R. Targeting hedgehog signaling in myelofibrosis and other hematologic malignancies. J Hematol Oncol. 2014;7(1):18.

82. Goel G, Sun W. Advances in the management of gastrointestinal cancers —an upcoming role of immune checkpoint blockade. J Hematol Oncol. 2015;8(1):86

83. Goel G, Sun W. Novel approaches in the management of pancreatic ductal adenocarcinoma: potential promises for the future. J Hematol Oncol. 2015:8(1):44

84. Lin A, Lin E. Programmed death 1 blockade, an Achilles heel for MMRdeficient tumors? J Hematol Oncol. 2015;8(1):124.

85. Tsai K, Daud A. Nivolumab plus ipilimumab in the treatment of advanced melanoma. J Hematol Oncol. 2015:8(1):123.

86. Fan G, Wang Z, Hao M, Li J. Bispecific antibodies and their applications. J Hematol Oncol. 2015;8(1):130.

87. Reusch U, Burkhardt C, Fucek I, Le Gall F, Le Gall M, Hoffmann K, et al. A novel tetravalent bispecific TandAb (CD30/CD16A) efficiently recruits NK cells for the lysis of CD30+ tumor cells. mAbs. 2014;6(3):728-39.
88. Robert C, Long GV, Brady B, Dutriaux C, Maio M, Mortier L, et al. Nivolumab in previously untreated melanoma without BRAF mutation. N Engl J Med. 2015;372(4):320-30.

89. Robert C, Schachter J, Long GV, Arance A, Grob JJ, Mortier L, et al. Pembrolizumab versus ipilimumab in advanced melanoma. N Engl J Med. 2015;372(26):2521-32.

90. Topp MS, Gokbuget N, Stein AS, Zugmaier G, O'Brien S, Bargou RC, et al. Safety and activity of blinatumomab for adult patients with relapsed or refractory B-precursor acute lymphoblastic leukaemia: a multicentre, single-arm, phase 2 study. Lancet Oncol. 2015;16(1):57-66.

91. Herbst RS, Baas P, Kim DW, Felip E, Perez-Gracia JL, Han JY, Molina J, Kim JH, Arvis CD, Ahn MJ, Majem M, Fidler MJ, de Castro G, Jr., Garrido M, Lubiniecki GM, Shentu Y, Im E, Dolled-Filhart M, Garon EB. Pembrolizumab versus docetaxel for previously treated, PD-L1-positive, advanced non-small-cel lung cancer (KEYNOTE-010): a randomised controlled trial. Lancet 2015, 286(10012):10.1016/S0140-6736(1015)01281-01287.

\section{Submit your next manuscript to BioMed Central and we will help you at every step:}

- We accept pre-submission inquiries

- Our selector tool helps you to find the most relevant journal

- We provide round the clock customer support

- Convenient online submission

- Thorough peer review

- Inclusion in PubMed and all major indexing services

- Maximum visibility for your research

Submit your manuscript at www.biomedcentral.com/submit
Biomed Central 